\title{
Molecular detection of enteropathogenic Escherichia coli in asymptomatic captive psittacines ${ }^{1}$
}

\begin{abstract}
André Becker Saidenberg'2*, Rodrigo Hidalgo F. Teixeira ${ }^{3}$, Neiva Maria R. Guedes ${ }^{4}$, Mariangela da Costa Allgayer ${ }^{5}$, Priscilla Anne Melville ${ }^{2}$ and Nilson Roberti Benites ${ }^{2}$

ABSTRACT.- Saidenberg A.B., Teixeira R.H.F., Guedes N.M.R., Allgayer M.C., Melvelville P.A. \& Benites N.R. 2012. Molecular detection of enteropathogenic Escherichia coli in asymptomatic captive psittacines. Pesquisa Veterinária Brasileira 32(9):922-926. Departamento de Medicina Veterinária Preventiva, Faculdade de Medicina Veterinária e Zootecnia, Universidade de São Paulo, Av. Prof. Dr. Orlando Marques de Paiva 87, São Paulo, SP 05508270, Brazil. E-mail: andresaidenberg@usp.br

Psittaciformes are one of the most endangered groups of birds, and several Brazilian species are classified between vulnerable and critically endangered. It is thus necessary to identify agents that cause infections in captive wild animals and to assess the risks posed thereof and to design interventions to minimize the possibility of disease outbreaks, leading to the conservation of endangered species. The purpose of this study was to identify enteropathogenic Escherichia coli (EPEC) cloacal isolates from asymptomatic psittacines in captivity and evaluate the distribution of the EPEC pathotype. Cloacal swabs were obtained from 46 asymptomatic birds, and resulting isolates were tested by polymerase chain reaction (PCR) for the presence of the attaching and effacing gene (eae) and bundle-forming pilus structural gene $(b f p A)$ of EPEC. Samples from several species were tested, and three samples were found to be positive for the eae and $b f p A$ genes and characterized as typical EPEC. This is the first report of this pathotype in asymptomatic psittacines. Although certain $E$. coli strains are more pathogenic than others, various factors should be considered when determining the potential of $E$. coli isolates to cause disease in captive psittacines. Birds that are positive for the EPEC (typical) strain could be zoonotic sources of infection, and may have acquired these strains through contact with humans or domestic animals. These findings may also be valuable for the long-term management of endangered species ex situ as one EPEC sample was isolated from a Red-tailed Amazon (Amazona brasiliensis).
\end{abstract}

INDEX TERMS: Enterobacteria, Escherichia coli, virulence factors, psittacines, wild birds.

RESUMO.- [Detecção molecular de Escherichia coli enteropatogênica em psitacídeos assintomáticos em cativeiro.] Os psitacídeos são um dos grupos de aves mais ameaçadas no mundo e diversas espécies brasileiras são

\footnotetext{
${ }^{1}$ Received on December 7, 2011.

Accepted for publication on May 5, 2012.

${ }^{2}$ Departamento de Medicina Veterinária Preventiva, Faculdade de Medicina Veterinária e Zootecnia (FMVZ), Universidade de São Paulo (USP), Av. Prof. Dr. Orlando Marques de Paiva 87, São Paulo, SP 05508-270, Brazil. *Corresponding author: andresaidenberg@usp.br

${ }^{3}$ Parque Zoológico Municipal, "Quinzinho de Barros", Sorocaba, SP 18021-020, Brazil. E-mail: rhftzoo@hotmail.com

${ }^{4}$ Programa de MDR, Universidade Anhanguera (Uniderp), Projeto Arara Azul, Campo Grande, MS 79051-660, Brazil. E-mail: guedesneiva@gmail.com

${ }^{5}$ Criatório Asas do Brasil, Novo Hamburgo ULBRA, Canoas, RS 96501595, Brazil. E-mail: mariangela@asasdobrasil.com.br
}

classificadas desde vulneráveis à criticamente ameaçadas de extinção. Torna-se, portanto, necessário identificar os agentes que causam infecções em animais selvagens em cativeiro e determinar os riscos relacionados de modo a intervir sobre os fatores envolvidos para diminuir a possibilidade de surtos de doenças e promover a conservação de espécies ameaçadas. 0 objetivo deste estudo foi identificar Escherichia coli Enteropatogência (EPEC) de isolados cloacais de psitacídeos assintomáticos em cativeiro e avaliar a distribuição do patotipo EPEC. Suabes cloacais foram coletados de 46 psitacídeos assintomáticos e os isolados foram testados pela reação em cadeia pela polimerase (PCR) para a presença do gene attaching and effacing (eae) e bundle forming pilus ( $b f p \mathrm{~A})$ de EPEC. Amostras oriundas de diversas espécies foram testadas e três amostras resultaram positivas para os genes eae e bfp e caracterizadas como EPEC 
típicas. Esse é o primeiro relato em psitacídeos assintomáticos para esse patotipo. Apesar de que algumas cepas de E.coli serem mais patogênicas do que outras, diversos fatores devem ser considerados para determinar o potencial de isolados de E.coli de causar doença em psitacídeos em cativeiro. Aves positivas para cepas de EPEC (típicas) poderiam ser fontes de infecção zoonóticas e adquirir essas cepas através do contato com humanos e animais domésticos. Esses achados também podem ser valiosos para o manejo a longo prazo de espécies ameaçadas ex situ já que uma amostra de EPEC foi isolada de um Papagaio-de-cara-roxa (Amazona brasiliensis).

TERMOS DE INDEXAÇÃO: Enterobactéria, Escherichia coli, fatores de virulência, psitacídeos, aves selvagens.

\section{INTRODUCTION}

Psittaciformes are one of the most endangered groups of birds in the world. The International Union for Conservation of Nature (IUCN) classified 15 out of the 84 Brazilian species between vulnerable and critically endangered (Snyder et al. 2000).

Identifying the presence of infectious agents and the risks that they may pose to captive collections of wild animals becomes extremely useful when designing interventions based on the factors involved to minimize the chance of disease outbreaks and facilitate conservation and maintenance of endangered species (Gomes, 2002).

Previous studies have established that the intestinal flora of healthy psittacines is primarily composed of Gram-positive bacteria (Bangert et al. 1988). Gram-negative bacteria have been found to cause bacterial enteritis resulting in intestinal disorders or septicemia and are considered pathogenic or opportunistic (Drewes \& Flammer 1986, Gerlach 1994).

Gram-negative bacteria may also be transient in the gastrointestinal tract and of little significance as long as the normal microbiota remains intact. However, if resident microbiota is disturbed, these Gram-negative bacteria may proliferate and cause disease (Dorrestein 1997).

For a long time, Escherichia coli (E. coli) was considered a commensal inhabitant without high pathogenic potential. However, several intestinal and extraintestinal diseases harboring E. coli-associated virulence factors have been reported. Molecular biology techniques have classified the virulence factors into pathotypes by detecting genes responsible for the expression of these virulence factors (Sussmann 1997).

The attaching and effacing $E$. coli (AEEC) pathotype has the ability to cause lesions on the intestinal mucosa leading to severe diarrhea. This is initiated by adherence of E. coli to the epithelial cell membrane, which is mediated by intimin, an adhesin encoded by the eae gene. This gene is located in the locus of enterocyte effacement, which is associated with enteropathogenic E. coli (EPEC), an important category of diarrheagenic E. coli (Nataro \& Kaper 1998). Typical EPEC strains possess intimin and the bundle-forming pilus structural gene $(b f p A)$ responsible for the first contact of the bacteria with the host cell (Trabulsi et al. 2002).
Some studies among wild birds have determined the classification of pathogenic E. coli strains (Foster et al. 1998, Steele et al. 2005), and those involving psittacines found a degree of correspondence between disease and certain pathotypes (Schremmer et al. 1999, Knöbl et al. 2008).

The purpose of this study was to identify E. coli cloacal isolates from healthy psittacines in captivity in Brazil and to determine whether sampling of a variety of birds of different origins could provide additional information on the distribution of the EPEC pathotype.

\section{MATERIALS AND METHODS}

This study was carried out from July 2009 to July 2011. Samples were obtained from random captive parrot species of all ages and sexes, which were maintained by breeders, rescue centers, and a zoological collection. Varied species comprising 24 Amazon parrots (Amazona aestiva, Amazona amazonica, Amazona brasiliensis, Amazona farinosa, Amazona pretrei, Amazona rhodocorytha, Amazona vinacea), 10 macaws (Ara ararauna, Ara chloroptera, Ara macao, Anodorhynchus hyacinthinus), and 12 conures (Aratinga aurea, Aratinga jandaya, Aratinga solstitialis, Guaruba guarouba Pyrrhura cruentata, Pyrrhura frontalis) were obtained, with at least two birds from each species, and maintained in different enclosures. They were fed with a commercial pellet diet, seeds, and complemented by fruits and vegetables; the aviary was cleaned on a daily basis (outdoor aviaries with sand substrate). Birds were maintained in flocks ranging from pairs to 10 individuals. The majority of birds were previously confiscated from the illegal trade by the Brazilian environmental authorities during different occasions and sent directly to these institutions or after receiving first-aid care at a CETAS (Centro de Triagem de Animais Silvestres), being maintained at these institutions for at least six months up to several years.

Cloacal swabs (CultureSwabs, DIFCOC Becton Dickenson and Company, Sparks, Maryland, USA) were taken from 46 asymptomatic birds that were considered to be clinically normal at the time of the sampling and afterwards (i.e., no history of health issues in the previous and following three months of the sampling, good pectoral muscles score, not presenting diarrhea/soiled feathers around the vent, prostration, or other unspecific signs of disease).

All swabs were refrigerated at $10^{\circ} \mathrm{C}$ (up to 5 days) until processing. The swabs were incubated in the Brain Heart Infusion broth (DIFCOC) for 24 hours at $37^{\circ} \mathrm{C}$ and then streaked onto MacConkey agar plates (DIFCOC) and incubated for 24 hours at $37^{\circ} \mathrm{C}$. E. coli colonies were biochemically characterized using an identification kit (Newprov (C), Brazil). Several colonies from each sample were mixed in $200 \mu \mathrm{L}$ of saline solution, and bacterial DNA was extracted according to established protocols (Boom et al. 1990 ) and stored at $-20^{\circ} \mathrm{C}$.

E. coli isolates were tested using polymerase chain reaction (PCR) for the presence of eae and $b f p A$ according to the described protocols (Aranda et al. 2007), employing as the positive control the EPEC strain (positive for the eae, bfpA genes) available at the collection of the Laboratório de Bacteriologia e Micologia da Faculdade de Medicina Veterinária e Zootecnia da Universidade de São Paulo (strain E2348/69).

PCR was performed in a $50 \mu \mathrm{L}$ reaction mixture, which contained $10 \mathrm{mM}$ Tris- $\mathrm{HCl}, 50 \mathrm{mM} \mathrm{KCl}, 1.5 \mathrm{mM} \mathrm{MgCl}, 2 \mathrm{mM}$ of each deoxynucleoside triphosphate, $1.5 \mathrm{U}$ Taq DNA polymerase (Invitrogen $^{\circledR}$ ), $2 \mu \mathrm{L}$ of the extracted DNA template, and each of the PCR primer pairs. The PCR cycles consisted of 1 cycle for 2 min at $50^{\circ} \mathrm{C}$, 1 cycle for $5 \mathrm{~min}$ at $95^{\circ} \mathrm{C}$, and 40 cycles for $1 \mathrm{~min}$ at $95^{\circ} \mathrm{C}, 1 \mathrm{~min}$ at 
$50^{\circ} \mathrm{C}$, and $1 \mathrm{~min}$ at $72^{\circ} \mathrm{C}$, and finally, 1 cycle for $7 \mathrm{~min}$ at $72^{\circ} \mathrm{C}$. The agarose gel was stained with ethidium bromide. Amplified fragments were visualized under ultraviolet light and identified with a 100 base pairs (bp) molecular ladder (Life Technologies@, Life Technologies do Brasil Ltda., São Paulo, Brazil).

\section{RESULTS}

Escherichia coli was isolated from all 46 psittacines. PCR revealed that three samples were positive for the eae and bfpA genes (918 bp and $325 \mathrm{bp}$ fragments respectively) (Fig.1.), which were characterized as typical EPEC. The species positive for EPEC consisted of one individual of Orange-winged Amazon (Amazona amazonica), one Red-tailed Amazon (Amazona brasiliensis), and one Blue and gold Macaw (Ara ararauna) (Table 1.). All these birds were housed at the same zoological collection, but in separate enclosures.

Samples obtained from other birds of the same species in the same enclosures did not yield EPEC-positive results (Table 1.).

\section{DISCUSSION}

Bacterial infections may be primary or secondary, and this differentiation is important for the evaluation of a disease process. After becoming established, many secondary invaders can maintain a disease independent of other infectious agents or predisposing conditions (Gerlach 1994).

Secondary infections due to poor daily care and immunosuppression are common in captive birds. Deficient diets expose birds to a large number of potentially infectious organisms, and immunosuppression may occur due to malnutrition, stress, or concurrent diseases (Flammer 1998).

Three samples in this study were characterized as typical EPEC. Humans are considered the primary reservoir for this pathotype (Trabulsi et al. 2002). Although positive samples have been found in dogs, cats, and nonhuman primates (Carvalho et al. 2003, Nakazato et al. 2004, Krause et al. 2005, Morato et al. 2008), this pathotype is very rare in

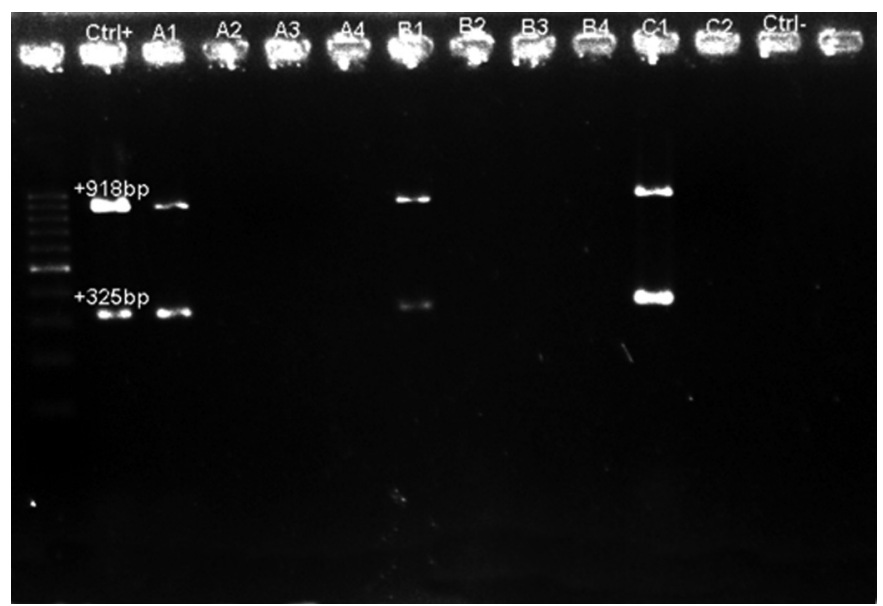

Fig.1. Picture of agarose gel stained with ethidium bromide showing the positive and negative results for the species of psittacines which yielded positive results for eae and bfpA genes of Enteropathogenic Escherichia coli. Lane 1: 100 bp molecular ladder (Life Technologies(C); CTRL +: Positive control EPEC strain E2348/69; A1-A4: Orange-winged Amazon (Amazona amazonica); B1-B4: Blue and Gold Macaw (Ara ararauna); C1 and C2: Red-tailed Amazon (Amazona brasiliensis); CTRL-: Negative control; Lane 14: Empty slot.

animals. Few studies in birds, mainly of atypical isolates in poultry, report presence of intimin (eae gene) but lack of the $b f p A$ gene found in typical EPEC, which facilitate contact with the enterocyte (Pakpinyo et al. 2002, Trabulsi et al. 2002).

Clinical cases of atypical EPEC were reported to cause massive death outbreaks in backyard passerines species (Foster et al., 1998). Rehabilitated asymptomatic seagulls were also positive for the eae gene (Steele et al., 2005). Other study surveying eae positive strains among wild birds in Korea also detected carriers for atypical $E$. coli isolates. Interestingly eae positive samples were also found among the recently described species Escherichia albertii. The isolates were found especially in aquatic birds and in a

Table 1. Species and positive culture results for Escherichia coli and tested genes by PCR for Enteropathogenic E. coli

\begin{tabular}{llcc}
\hline \multicolumn{1}{c}{ Species } & \multicolumn{2}{c}{$\begin{array}{c}\text { Number of positive } \\
\text { cultures for E. coli }\end{array}$} & $\begin{array}{c}\text { Number of positive E. coli sam- } \\
\text { ples for the, surveyed genes }\end{array}$ \\
\cline { 2 - 3 } & & eae & bfp \\
\hline Blue-fronted Amazon (Amazona aestiva) & 10 & 0 & 0 \\
Mealy Amazon (Amazona farinosa) & 2 & 0 & 1 \\
Orange-winged Amazon (Amazona amazonica) & 4 & 1 & 0 \\
Red-browed Amazon (Amazona rhodocorytha) & 2 & 0 & 0 \\
Red-spectacled Amazon (Amazona pretrei) & 2 & 0 & 1 \\
Red-tailed Amazon (Amazona brasiliensis) & 2 & 1 & 0 \\
Vinaceous Amazon (Amazona vinacea) & 2 & 0 & 1 \\
Blue and Gold Macaw (Ara ararauna) & 4 & 1 & 0 \\
Hyacinth Macaw (Anodorhynchus hyacinthinus) & 2 & 0 & 0 \\
Green-winged Macaw (Ara chloroptera) & 2 & 0 & 0 \\
Scarlet Macaw (Ara macao) & 2 & 0 & 0 \\
Blue-throated parakeet (Pyrrhura cruentata) & 2 & 0 & 0 \\
Golden conure (Guaruba guarouba) & 2 & 0 & 0 \\
Jandaya parakeet (Aratinga jandaya) & 2 & 0 & 0 \\
Maroon-bellied parakeet (Pyrrhura frontalis) & 2 & 0 & 0 \\
Peach-fronted parakeet (Aratinga aurea) & 2 & 0 & 0
\end{tabular}


lesser degree among Passeriformes and Piciformes (Oh et al. 2011).

In a study involving psittacines, four isolated samples were characterized as typical EPEC and three as atypical isolates, all of which originated from clinical cases of diarrhea, enteritis, or septicemia, and suggested that these $E$. coli could have implications for human health (Schremmer et al. 1999).

It is possible to hypothesize that birds, especially those positive for the EPEC (typical), which are frequent human pathogens (Nataro \& Kaper 1998), could be zoonotic sources of infection and that they may have acquired these Escherichia coli strains through direct or indirect contact with humans and domestic animals. This has been suggested as a transmission form among pets, exemplifying the possibility of cross-species infection (Nakazato et al. 2004).

The present findings may also be valuable for the management of endangered species of psittacines in captivity as one positive sample for EPEC belonged to a Red-tailed Amazon (Amazona brasiliensis). This could imply potential risks that need to be appropriately addressed to achieve a long-term successful captive breeding program and maintenance of founder populations (Deem et al. 2008). This is also the first report of EPEC in asymptomatic psittacines.

Previous studies showed that some virulence factors are indeed involved with several clinical cases of colibacillosis in psittacines (Schremmer et al. 1999, Knöbl et al. 2008, 2011). The present work has found three carriers that were positive for virulence factors that would be assumed to be found only in cases leading to serious symptoms and death. It is also interesting to notice that the EPEC-positive birds were housed together with others of the same species that nevertheless yielded negative-EPEC results. This could possibly indicate either an intermittent shedding or a transient carrier state among the positive individuals.

Maintenance of a carrier state could be related to the fact that birds had access to the ground as they were maintained in outdoor enclosures, hence being able to reinfect themselves or possibly the companions at some point while in contact with fecal material. Even though the excess food and fecal material can be removed daily from the sand substrate, concrete substrates or suspended enclosures are preferable in order to break the cycle of reinfection as carriers for Gram-negative bacteria can eliminate the organisms by themselves if maintained with proper husbandry (Stanford 2003).

In captivity, psittacines are exposed to a number of factors that potentially lead to disease in the long term by causing immunosuppression due to physical or psychological conditions such as inadequate hygiene, mycotoxins, deficient diets, lack of mental stimulus and socialization, sexual frustration, and neglect, any or all of which may determine the course of disease after exposure to an infectious agent (Ness 2006).

It is known that considering all Gram-negative bacteria as pathogens would lead to unnecessary antibiotic treatment (Flammer \& Drewes 1988). Thus, the clinician must determine the importance of bacterial isolation for a spe- cific bird species and a specific process to appropriately interpret culture results (Gerlach 1994). However, disregarding culture results in some instances could be as dangerous as over interpreting them.

In asymptomatic birds, Gram-negatives should be viewed not as a cause of alarm but instead as an early indication of the need of better husbandry practices, thus minimizing the risk of disease development even if the bacteria would probably just act as an opportunistic pathogen in the future. The real issue might not be whether certain strains are pathogenic or not, but when they are able to cause disease, and under what circumstances they are capable, even as transient organisms, to proliferate and lead to clinical signs. As described here, all positive birds and their companions were asymptomatic at the time of sampling and during the subsequent three months of follow-up. Nevertheless, the possibility of developing disease at a certain period in the future and/or transmitting to other animals, including humans, should be viewed as an early warning and as an opportunity to implement preventive husbandry measures. Changes involving suspended enclosures or at least a concrete substrate, which allows thorough daily disinfection would be preferred in order to enhance husbandry at these institutions.

All environments contain organisms that can cause disease; however, these organisms cause disease only when allowed to reach high concentrations or when husbandry practices are less than ideal. Consequently, diseases can be greatly minimized by implementing proper hygiene conditions (Phalen 2006).

\section{CONCLUSION}

The isolation of EPEC carriers in this study indicates that although certain strains are more pathogenic than others, various inherent factors regarding the maintenance of psittacines in captivity may be involved and should be considered in order to determine when an Escherichia coli strain will cause disease. Further studies using diverse populations, husbandry practices, and species could provide additional information on the subject and lead to improvement of the quality of life and conservation of the species.

Acknowledgements.- To Fundação de Amparo à Pesquisa do Estado de São Paulo (FAPESP) for the financial support (Grant 2010/51015-0). In addition, the author is grateful for the help provided by the Instituto Arara Azul and Asas do Brasil breeding center.

\section{REFERENCES}

Aranda K., Fabbricotti S.H., Fagundes-Neto U. \& Scaletsky I.C.A. 2007. Single multiplex assay to identify simultaneously Enteropathogenic, Enteroaggregative, Enterotoxigenic, Enteroinvasive and Shiga toxin producing Escherichia coli strains in Brazilian children. FEMS Microbiol. Lett. 267:145-150.

Bangert R.L., Cho B.R., Widders P.R., Stauber E.H. \& Ward C.S. 1988. A survey of aerobic bacteria and fungi in the feces of healthy psittacine birds. Avian Dis. 32:46-52.

Boom R., Sol C.J.A., Salimans M.M.M., Jansen C.L., Werthein-van Dillen P.M.E. \& Van der Noordaa L. 1990. Rapid and simple method for purification of nucleic acids. J. Clin. Microbiol. 28:495-503.

Carvalho V.M., Gyles C.L., Ziebell K., Ribeiro M.A., Catão-Dias J L., Sinhorini I.L., Otman J., Keller R., Trabulsi L.R. \& Pestana de Castro A.F. 2003. Cha- 
racterization of monkey Enteropathogenic Escherichia coli (EPEC) and human typical and atypical EPEC serotype isolates from Neotropical nonhuman primates. J. Clin. Microbiol. 41:1225-1234.

Deem S., Ladwig E., Cray C., Karesh W.B. \& Amato G. 2008. Health assessment of the ex situ population of St Vincent parrots (Amazona guildingii) in St Vincent and the Grenadines. J. Avian Med. Surg. 22:114-122.

Dorrestein G.M. 1997. Bacteriology, p.255-280. In: Altman R.B., Clubb S.L., Dorrestein G.M. \& Queseberry K. (Eds), Avian Medicine and Surgery. W.B. Saunders Company, Philadelphia.

Drewes L.A. \& Flammer K. 1986. Clinical microbiology, p.157-171. In: Harrison G.J. \& Harrison L.R. (Eds), Clinical Avian Medicine and Surgery. W.B. Saunders, Philadelphia.

Flammer K. 1998. Common bacterial infections and antibiotic use in companion birds. Sup. Compend. Cont. Educ. Pract. Vet. 20:34-48.

Flammer K. \& Drewes L.A. 1988. Species related differences in the incidence of gram-negative bacteria isolated from the cloaca of clinically normal psittacine birds. Avian Dis. 32:79-83.

Foster G., Ross H.M., Pennycott T.W., Hopkins G.F. \& McLaren I.M. 1998. Isolation of Escherichia coli 086:K61 producing cyto-lethal distending toxin from wild birds of the finch family. Lett. Appl. Microbiol. 26:395-398.

Gerlach H. 1994. Bacteria, p.949-983. In: Ritchie B.W., Harrison G.J. \& Harrison L.R. (Eds), Avian Medicine: Principles and application. Wingers Publishing Inc., Lake Worth, Florida.

Gomes M.S. 2002. Implantação de medidas profiláticas no Zoológico do Município de São Bernardo do Campo: uma análise de custo - benefício. Dissertação de Mestrado em Epidemiologia Experimental Aplicada às Zoonoses, Faculdade de Medicina Veterinária e Zootecnia, Universidade de São Paulo, São Paulo, SP. 97p.

Knöbl T., Godoy S.N., Matushima E.R., Guimarães M.B. \& Ferreira A.J.P. 2008. Caracterização molecular dos fatores de virulência de estirpes de Escherichia coli isoladas de papagaios com colibacilose aviária. Braz. J. Vet. Res. Anim. Sci. 45:54-60.

Knöbl T., Saidenberg A.B.S., Moreno A.M., Gomes T.A.T., Vieira M.A.M., Leite D.S., Blanco J.E. \& Ferreira A.J.P. 2011. Serogroups and virulence genes of Escherichia coli isolated from psittacine birds. Pesq. Vet. Bras. 31:916921.

Krause G., Zimmermann S. \& Beutin L. 2005. Investigation of domestic animals and pets as a reservoir for intimin (eae) gene positive Escherichia coli types. Vet. Microbiol. 106:87-95.
Morato E.P., Leomil L., Beutin L., Krause G., Moura R.A. \& Pestana de Castro A.F. 2008. Domestic cats constitute a natural reservoir of human enteropathogenic Escherichia coli types. Zoon. Public. Hlth 56:229-237.

Nakazato G., Gyles C., Ziebell K., Keller R., Trabulsi L.R., Gomes T.A., Irino K., da Silveira W.D. \& Pestana de Castro A.F. 2004. Attaching and effacing Escherichia coli isolated from dogs in Brazil: Characteristics and serotypic relationship to human Enteropathogenic E. coli (EPEC). Vet. Microbiol. 101:269-277.

Nataro J.P. \& Kaper J.B. 1998. Diarrheagenic Escherichia coli. Clin. Microbiol. 11:142-201.

Ness R.D. 2006. Integrative therapies, p.343-364. In: Harrison G.J. \& Lightfoot T.L. (Eds), Clinical Avian Medicine. Spix Publishing, Florida.

Oh J.Y., Kang M.S., Hwang H.T., An B.K., Kwon J.H. \& Kwon Y.K. 2011. Epidemiological investigation of eaeA-positive Escherichia coli and Escherichia albertii strains isolated from healthy wild birds. J. Microbiol. 49: 747-752.

Pakpinyo S., Ley D.H., Barnes H.J., Vaillancourt J.P. \& Guy J.S. 2002. Prevalence of Enteropathogenic Escherichia coli in naturally occurring cases of poult enteritis-mortality syndrome. Avian Dis. 46:360-369.

Phalen D.N. 2006. Preventive medicine and screening, p.573-585. In: Harrison G.J. \& Lightfoot T.L. (Eds), Clinical Avian Medicine. Spix Publishing, Florida.

Schremmer C., Lohr J.E., Wastlhuber U., Kösters J., Ravelshofer K., Steinrück H. \& Wieler L.H. 1999. Enteropathogenic Escherichia coli in Psittaciformes. Avian Pathol. 28:349-354.

Snyder N., McGowan P., Gilardi J. \& Grajal A. 2000. The world parrot trust, gland, p.98-151. In: Snyder N., McGowan P., Gilardi J. \& Grajal A., (Eds), Parrots: Status Survey and Conservation Action Plan 2000-2004. IUCN, Switzerland and Cambridge, Oxford, UK.

Stanford M. 2003. Effects of dietary change on fecal Gram's stains in the African grey parrot. Exotic DVM 4:12-13.

Steele C.M., Brown R.N. \& Botzler R.G. 2005. Prevalences of zoonotic bacteria among seabirds in rehabilitation centers along the pacific coast of California and Washington, USA. J. Wildlife Dis. 41:735-744.

Sussmann M. 1997. Escherichia coli and human disease, p.3-48. In: Sussmann M. (Ed.), Escherichia coli Mechanisms of Virulence. University Press, Cambridge, UK.

Trabulsi L.R., Keller R. \& Gomes T.A.T. 2002. Typical and atypical enteropathogenic Escherichia coli. Emerg. Infect. Dis. 8:508-513. 